\title{
BACTERIOLOGICAL QUALITY OF ICE AND ASSOCIATED SANITARY CONDITIONS IN FOOD AND BEVERAGE PREMISES IN THASALA, NAKHON SI THAMMARAT, THAILAND
}

\author{
Pattida Thongkaow ${ }^{1}$, Amornrat Kummuda ${ }^{1}$, Sofiya Sawee ${ }^{1}$ and Prasert Makkaew ${ }^{1 *}$ \\ ${ }^{1}$ Department of Environmental Health and Technology, School of Public Health, Walailak University \\ Corresponding author: Prasert Makkaew \\ Email: mprasert@mail.wu.ac.th
}

\begin{abstract}
Ice is widely used in food and drink establishments for refreshing drinks and food preservation. Therefore, the contamination of ice, especially microbial contamination, could be the vehicle for transmission of pathogenic microorganisms to consumers. This study aimed to determine of bacteriological quality of ice sold at food and beverage premises. The sanitary conditions of the premises were also investigated. Edible ice samples from 12 premises were collected and analyzed coliform bacteria using the multiple-tube fermentation technique. Modified food sanitation inspection form from the Bureau of Food and Water Sanitation, Department of Health, Ministry of Public Health, was used for inspection of food and beverage premises. It was found that all samples were positive for coliform bacteria, ranging from $140-\geq 24,000 \mathrm{MPN} / 100 \mathrm{~mL}$, which is inconsistent with the standard permission level in terms of total coliform bacteria of Thailand office of Food and Drug Administration. Ice storage and handwashing

behavior of food handlers were the main sanitary issues found from the sanitary conditions survey. The finding of this study urges the regulatory guidelines for monitoring of ice quality and the sanitary conditions of food and beverage premises to protect the consumers' health from the consumption of unsafe ice.
\end{abstract}

Keywords: Bacteriological quality, Ice, Food and beverage, Sanitary conditions

\section{INTRODUCTION}

Thailand is located in a tropical area, which could be described as hot and humid almost all year round; therefore, ice plays an important role for Thai people in daily life. The benefit of ice is not only for consumption, but also for food preservation, and fishery industry. Microbiological hazards are one of the public health concerns which could be found along the ice supply chain, from the manufacturing plants to the point of sales. Therefore, "ice" is defined as "special controlled food" according to the Ministry of Public Health Notifications No.78 B.E.2527 and No. 137 B.E. $2534^{1}$. Moreover, ice-making factories are controlled by the Thai Good Manufacturing Practice (GMP) Law, which was adapted from the General Principles of Food Hygiene of the CODEX Alimentarius Commission ${ }^{2}$

However, ice could be contaminated not only in manufacturing plants but also in transportation, and retails including food and beverage premises. Worldwide, several studies have been investigated the microbiological quality of ice and have confirmed the microbial contamination in the production plants, retails and food and beverage premises. Psudomonas aeruginosa ( $P$. aeruginosa), Staphylococcus aureus (S. aureus), Escherichia coli (E. coli), Enterrocooci, and fungi have been detected in Italy ${ }^{3}$, Staphylococci and $E$. coli in the USA ${ }^{4}$, E. coli and Enterococci in Turkey ${ }^{5}$, fecal coliforms in Malaysia ${ }^{6}$, Vibrio cholerae (V. Cholerae) in Indonesia ${ }^{7}, P$. aeruginosa and Yersinia spp. in Greece $^{8}$. Moreover, antibioticresistant $E$. coli have been isolated from ice in Vietnam?.

Thailand is well known as a food lover's paradise, where food and beverage premises are easily accessible. Ice is often used in these premises and is generally consumed by the consumers. Therefore, ice could be a potential vehicle for food and water-borne transmission if it was contaminated by pathogens. Moreover, the outbreaks of gastroenteritis caused by contaminated ice have been reported worldwide, including Thailand ${ }^{10}$. In Thailand, there was a report of hepatitis A outbreak in the northern part that linked to the consumption of ice cubes ${ }^{10}$. Also, microbial contamination in edible ice from food and beverage premises has been reported ${ }^{11-}$ 13. Jongsamak, Chareonteeraboon, and Techaarpornkul found coliform bacteria in all ice samples sold at food premises in a university campus in the central region of Thailand, and 54\% was positive for S. aureus. They also observed that $8 / 13$ premises were unsatisfied in terms of sanitary conditions ${ }^{12}$, which could be the important source of microbial contamination in those ice.

Therefore, the objectives of this study are to (1) determine the bacteriological quality of ice in 
terms of coliform bacteria, (2) inspect the sanitary conditions of food and beverage premises where ice is sold. The study has been carried out in Thasala district, Nakhon $\mathrm{Si}$ Thammarat province, Thailand. The results from this study will provide the baseline data to the local government organization to assess the public health risk of edible ice as well as to give the information in setting guidelines for the sanitary inspection of ice in food and beverage premises.

\section{METHODS}

This cross-sectional study was conducted in 12 food and drink premises where were 2 Kilometer radius from Walailak University, Thasala, Nakhon Si Thammarat, Thailand. All 12 premises were purposely sampling according to their owners' permission to participate in this study, and food and beverage premises that did not sell ice at a time of collection were excluded in this study. Ice samples were collected approximately $500 \mathrm{~g}$ from each premise. The samples were collected by an aseptic technique and put into a sterile plastic bag, labeled the sample code and collected date, and put it into a foam container and transported immediately to the Environmental Health Laboratory, the Center for Scientific and Technological Equipment, Walailak University where they were analyzed within 2 hours of collection. The sanitary conditions of the premises were also inspected. Data collection was done accompanied by a public health officer who was responsible for the area where the studied premises were located.

\section{Analysis of coliform bacteria}

In this study, the fecal indicating bacteria, coliforms was used to represent the microbiological quality of ice. The multiple-tube fermentation technique and expressed in terms of the Most Probable Number $(5 \times 3$ tubes MPN method) were used to quantify coliform bacteria. Inoculate 15 tubes (5 with $10 \mathrm{~mL}$ of sample into Double-strength Lactose broth tubes; 5 tubes with $1.0 \mathrm{~mL}$ each and 5 tubes with $0.1 \mathrm{~mL}$ each) into single-strength Lactose broth tubes, and incubate at $35^{\circ} \mathrm{C}$ for 48 hours. All the tubes showing gas and turbidity were recorded as positive tubes. Then, the confirmed test was performed by using inoculating loops to transfer from positive tubes to Brilliant green lactose $2 \%$ bile broth, after that incubated at $35^{\circ} \mathrm{C}$ for 48 hours. All the tubes showing gas and turbidity were recorded, and the MPN table for the 5-tubes was used to estimate the coliforms densities ${ }^{14}$.

\section{Sanitary conditions inspection}

The sanitary conditions at food and beverage premises were inspected based on 6 items, including display and storage, dishwashing facilities, wastewater and garbage disposal, toilets and their sanitary facilities, hygiene of food handlers, and handwashing behavior. These criteria were specified in the Clean Food Good Taste standard in Thailand, which is a basic sanitary standard for the restaurant of the Bureau of Food and Water Sanitation, Department of Health, Ministry of Public Health ${ }^{15}$. However, the inspection form was modified to more fit with food and beverage premises where the operation is smaller, comparing with the restaurant. The inspection was performed by two trained research assistants under the supervision of a public health officer and two researchers. The inspection and observation were carried out during the normal operation, while the staff was doing their routine activity in the premises.

\section{RESULTS}

In this study, ice samples were collected from 12 food and drink premises where ice is sold to analyze coliform bacteria. Sanitary conditions of these premises were also inspected.

\section{Bacteriological quality of ice}

Coliform bacteria were found in all samples, ranging from $140-\geq 24,000 \mathrm{MPN} / 100 \mathrm{~mL}$, which are inconsistent with the microbiological standard of Thailand office of the Food and Drug Administration (2.2 MPN/ $100 \mathrm{~mL})^{16}$. The results of the bacteriological quality of ice are shown in Table 1. The contamination of coliforms in ice samples of this study implies public health risk concerns as the coliforms are indicator organisms of sanitation. The presence of coliforms indicates the possible fecal contamination, the potential presence of pathogenic microorganisms, which used to evaluate the hygienic conditions in food and water industries ${ }^{17}$.

Sanitary conditions of food and drink premises This study inspected a total of 12 food and beverage premises, which consists of 4 beverages, 3 desserts, 3 ready-to-eat food, and 2 cooked-to-order dish premises. Sanitary conditions of food and beverage establishments where ice is sold were evaluated with "Complied" and "Not complied" in 6 items following the standard of Bureau of Food and Water Sanitation, Department of Health, Ministry of Public Health. The results showed that the top 3 compliance items were found in items $1.1,1.2$ and 2 which are; Kept in clean and closed containers $(75 \%)$, proper utensils (long handle spoon/ scoop) shall be used to pick up ice for serving (67\%), and dishwashing facilities shall be set at least $60 \mathrm{~cm}$ above the floor $(67 \%)$, respectively. However, no premises complied with the sanitary conditions in the items of 1.3 (ice containers shall be kept at least $60 \mathrm{~cm}$ above the floor), and 6 (food handlers must wash their hands frequently and thoroughly before preparing, cooking or handling food and ice or whenever else necessary). The detail of the findings is shown in Table 2. 
Table 1. Bacteriological quality of ice

\begin{tabular}{lc}
\hline Ice sample number & $\begin{array}{c}\text { MPN Index } \\
\text { (Total Coliform Bacteria/ 100 mL) }\end{array}$ \\
\hline 101 & 240 \\
102 & 240 \\
103 & 900 \\
104 & $\geq 24,000$ \\
105 & 240 \\
106 & 1,600 \\
107 & 540 \\
108 & 540 \\
109 & 540 \\
110 & 140 \\
111 & 240 \\
112 & 350 \\
\hline
\end{tabular}

Table 2. Sanitary conditions of food and drink establishments

\begin{tabular}{|c|c|c|}
\hline \multirow{2}{*}{ Item } & \multicolumn{2}{|c|}{ Compliance $(n=12)$} \\
\hline & Complied & Not complied \\
\hline \multicolumn{3}{|l|}{ 1. Ice display and storage } \\
\hline 1.1 Kept in clean and closed containers. & $9 / 12(75 \%)$ & $3 / 12(25 \%)$ \\
\hline $\begin{array}{l}\text { 1.2 Proper utensils (long handle spoon/scoop) shall be } \\
\text { used to pick up ice for serving. }\end{array}$ & $8 / 12(67 \%)$ & $4 / 12(33 \%)$ \\
\hline $\begin{array}{l}1.3 \text { Ice containers shall be kept at least } 60 \mathrm{~cm} \text { above } \\
\text { the floor. }\end{array}$ & $0 / 12(0 \%)$ & $12 / 12(100 \%)$ \\
\hline $\begin{array}{l}\text { 1.4 The ice/ containers must not be used to store raw } \\
\text { or other food in the same containers. }\end{array}$ & $7 / 12(59 \%)$ & $5 / 12(41 \%)$ \\
\hline $\begin{array}{l}\text { 2. Dishwashing facilities shall be set at least } 60 \mathrm{~cm} \\
\text { above the floor. }\end{array}$ & $8 / 12(67 \%)$ & $4 / 12(33 \%)$ \\
\hline $\begin{array}{l}\text { 3. Wastewater and garbage must be disposed of in such } \\
\text { a manner of sanitary method. }\end{array}$ & $6 / 12(50 \%)$ & $6 / 12(50 \%)$ \\
\hline $\begin{array}{l}\text { 4. Toilets must be clean, located separately from food } \\
\text { preparation, storage, cooking, and washing areas with } \\
\text { adequate sanitary facilities, including soap and hand } \\
\text { drying facilities. }\end{array}$ & $6 / 12(50 \%)$ & $6 / 12(50 \%)$ \\
\hline $\begin{array}{l}\text { 5. Food handlers must wear suitable protective clothing, } \\
\text { including short or long sleeves clothes, apron, and hair } \\
\text { covering (i.e., hat or net). }\end{array}$ & $4 / 12(33 \%)$ & $8 / 12(67 \%)$ \\
\hline $\begin{array}{l}\text { 6. Food handlers must wash their hands frequently and } \\
\text { thoroughly before preparing, cooking or handling food } \\
\text { and ice or whenever else necessary. }\end{array}$ & $0 / 12(0 \%)$ & $12 / 12(100 \%)$ \\
\hline
\end{tabular}

\section{DISCUSSION}

Commercial edible ice can be a transmission vehicle for many pathogenic microorganisms related to foodborne diseases when good hygiene and sanitation are not employed. Ice sold in food and beverage premises in this study was all tube ice, which was delivered from tube ice factories in town by containing in sacks and transported by pickup trucks or sidecars. Therefore, bacterial contamination of ice could be attributed to icemaking factories, transportation, and handling at the establishments. At the ice-making factories,
Chavasit et al. ${ }^{18}$ found that the potential sources of microbial contamination were condensate in tube ice production machines and improper disinfected sacks used for transportation. Moreover, Pusparini et al. ${ }^{19}$ reported the high diversity of 120 E. coli isolates of ice samples from ice cube production sites in Indonesia. Although ice-making factories in Thailand are being controlled by GMP law, ice manufacturers are not always able to control the microbial quality of products and sanitary conditions of production sites $^{20}$. 
Transportation is the other significant source of microbial contamination in ice, which should be a concern. In this study, ice was transported from the factories by pickup trucks or sidecars, which similar to other South East Asian Countries such as Vietnam ${ }^{9}$ and the Philippines ${ }^{21}$, where ice is transported by unsanitary vehicles. Therefore, post-production, such as transportation, should be regulated to reduce microbial contamination. Therefore, the microbial safety of ice along the ice chain, from the production site, transportation, to the point of sale should be investigated to minimize the public health risk of consumers.

Subsequently, upon transportation, the results of sanitary conditions inspection of food and beverage premises showed that they will often store ice in foam or plastic containers on the floor. In this study, $100 \%(12 / 12)$ put ice containers on the floor, which could be contaminated by the environment. Although, $41 \%$ $(5 / 12)$ of studied premises did not comply with the criterion of "The ice/ containers must not be used to store raw or other food in the same containers.", it was found that the ice samples collected from these two out of five premises, which were cooked-to-order dish premises have a high number of coliform bacteria, which were 104 $(\geq 24,000 \mathrm{MPN} / 100 \mathrm{~mL})$, and $106(1,600 \mathrm{MPN} / 100$ $\mathrm{mL}$ ), respectively. It is implied that the crosscontamination could have occurred in the containers between ice and raw food contained in the ice containers. In addition, both premises used cups as ice scoops which could pose a greater risk from ice contamination by contacting with the food handler's hand. Also, most of the food handlers in this study handle their ice without washing hands frequently, which may also cause microbial contamination in ice. Hence, proper handwashing should be promoted among food handlers as it has been approved that it could reduce the microbial load and prevent the spread of infectious diseases $22-23$.

\section{CONCLUSION}

The results indicated that coliform bacteria were found in all ice samples from food and beverage premises, which are inconsistent with the criteria for the microbiological quality of ice of the office of the Food and Drug Administration, Thailand. Furthermore, all the food and beverage premises did not comply with the sanitary condition standard. Therefore, they can play an essential role in the microbial contamination of ice due to the ice handling and personnel hygiene of food handlers. Therefore, it is highly recommended that monitoring of ice post-production, including transportation and handling at the point of sale, should be regulated to reduce the health risk of consumers.

\section{Conflict of interest}

The authors declare no potential conflict of interest.

\section{Acknowledgements}

We would like to express our thanks to the staff of Thasala Municipality Office for their help with data collection. We are also grateful to the staff of the Center for Scientific and Technological Equipment, Walailak University for laboratory work. This study was funded by the Walailak University Undergraduate Research Grant.

\section{REFERENCES}

1. Thailand Office of Food and Drug Administration. Manual of ice production site inspection following GMP regulation (In Thai). Nontaburi: The Agricultural Cooperative Federation of Thailand:2003.

2. CODEX Alimentarius. General principles of food hygiene 2019 [Internet]. [cited 2019 November 15]. Available from: http://www.fao.org fao-who-

codexalimentarius/sh-

proxy/en/?nk=1\&url=https $\% 253 \mathrm{~A} \% 252 \mathrm{~F} \% 252$

Fworkspace.fao.org $\% 252$ Fsites $\% 252$ Fcodex $\% 252$ FStandards $\% 252$ FCXC $\% 2 B 1$.

1969\%252FCXP_001e.pdf.

3. Caggiano $G$, Marcotrigiano $V$, Trerotoli $P$, Diella G, Rutigliano S, Apollonio F, et al. Food hygiene surveillance in Italy: Is food ice a public health risk? Int J Environ Res Public Health 2020;17(7): 2408.

4. Lee KH, Ab Samad LS, Lwin PM, Riedel SF, Magin A, Bashir $M$, et al. On the rocks: microbiological quality and microbial diversity of packaged ice in Southern California.J Food Prot 2017;80(6): 1041-9.

5. Hampikyan H, Bingol EB, Cetin O, Colak H. Microbiological quality of ice and ice machines used in food establishments. $J$ Water Health 2017;15(3):410-7.

6. Mahat N, Meor Ahmad Z, Abdul Wahab R. Presence of faecal coliforms and selected heavy metals in ice cubes from food outlets in Taman Universiti, Johor Bahru, Malaysia. Trop Biomed 2015;32(3):471-7.

7. Waturangi $D E$, Wennars $M$, Suhartono $M X$, Wijaya YF. Edible ice in Jakarta, Indonesia, is contaminated with multidrug-resistant Vibrio cholerae with virulence potential. J Med Microbiol 2013;62(3):352-9. 
8. Gerokomou V, Voidarou C, Vatopoulos A, Velonakis E, Rozos G, Alexopoulos A, et al. Physical, chemical and microbiological quality of ice used to cool drinks and foods in Greece and its public health implications. Anaerobe 2011;17(6):351-3.

9. Nakayama T, Ha NC, Quoc Le P, Kawahara $\mathrm{R}$, Kumeda $\mathrm{Y}$, Sumimura $\mathrm{Y}$, et al. Consumption of edible ice contaminated with Acinetobacter, Pseudomonas, and Stenotrophomonas is a risk factor for fecal colonization with extendedspectrum B-lactamase-producing Escherichia coli in Vietnam. J Water Health. 2017;15(5):813-22.

10. George. Freeze on ice production after hepatitis outbreak [Internet]. [cited 2021 April 13]. Available from: https:/forum thai -ice-production-afterhepatitis-outbreak/.

11. Yodmanee S, Cheloh S, Kalupae P, Pakdeechanuan P. Analysis of microbiological safety of ice in Pattani, Yala, and Narathiwat (In Thai). J Yala Rajabhat Univ 2012;7(1):24-34.

12. Jongsamak P, Chareonteeraboon J, Techaarpornkul S. A microbiological safety survey of edible ice at cafeterias and a weekly market of Silapakorn University, Sanamchandra Palace (In Thai). Thai Bull Pharm Sci 2015;9(1):14-23.

13. Paosungnern A, Lajamnong $\mathrm{S}$, Chimkul $\mathrm{S}$, Kongmuang S, Pinyowong W. Coliform bacteria contamination on ice and sanitation of the retail shops and refreshment stalls at the front of Nakhon Ratchasima Rajabhat University (In Thai) J PKRU SciTech 2017;1(1):10-8.

14. APHA. Standard methods for the examination of water and wastewater, $23^{\text {rd }}$ edition. American Public Health Association:2017.

15. Bureau of Food and Water Sanitation. Food sanitation inspection form for food serviceestablishments 2019 (In Thai) [Internet]. [cited 2019 November 16]. Available from
ad/D_CFGT/Standard/Inspection $\% 20$ form $\% 2$ Ofor\%20foodservice.pdf.

16. Thailand Office of Food and Drug Administration. Notification of the Ministry of Public Health No.78 B.E. 25272019 (In Thai). [cited 2019 November 17]. Available from: http: / / food.fda.moph.go.th/law/data/annou n_moph/V.English/No.78-27\%20ice.pdf.

17. Gleeson C, Gray N. The coliform index and water-borne disease: problems of microbial drinking water assessment: CRC Press:1996.

18. Chavasit V, Sirilaksanamanon K, Phithaksantayothin P, Norapoompipat Y, Parinyasiri T. Measures for controlling safety of crushed ice and tube ice in developing country. Food Control 2011;22(1):118-23.

19. Pusparini N, Waturangi DE, Usia $T$, Nikastri E. Genetic diversity of Escherichia coli isolated from ice cube production sites. BMC Res Notes 2018;11(1):1-8.

20. Tantrakarnapa K, Makkaew P, Vatanasomboon $\mathrm{P}$, Kengganpanich $\mathrm{T}$. Association of sanitary conditions and bacteriological quality of tube ice in ice plants in Metropolitan Bangkok, Thailand. Environmentasia 2010;3(1):8-12.

21. Salazar LF, Alvez TAI, Balbedina JMB, Torres JAA, Tupaz IY, Lomboy MFTC, et al. Physico-chemical and microbiological quality assessment of ice blocks sold in selected wet markets in Manila, Philippines. Acta Med Philippi 2018;52(3):232

22. Burton $M$, Cobb E, Donachie $P$, Judah $G$, Curtis V, Schmidt W-P. The effect of handwashing with water or soap on bacterial contamination of hands. Int J Environ Res Public Health. 2011;8(1):97104.

23. Nasution TA, Yunita R, Pasaribu AP, Ardinata FM. Effectiveness Hand Washing and Hand Rub Method in Reducing Total Bacteria Colony from Nurses in Medan. Open Access Maced J Med Sci 2019;7(20):3380-3383. 